\title{
Effect of Dietary Xylanase on Growth Performance, Digestive Enzymes and Physiological Responses of Nile Tilapia, Oreochromis Niloticus Fingerlings Fed Plant- Based Diets \\ Mohammed A. El-ashry ${ }^{1}$, Ahmed A. Radwan ${ }^{1}$, Abdelkarim I. M. El-Sayed ${ }^{1}$, Magdy A. Soltan ${ }^{1}$, Ahmed I. Mehrim $^{2}$ \\ ${ }^{1}$ Animal production department, Faculty of Agriculture, Benha University. ${ }^{2}$ Animal production department, Faculty of Agriculture, Mansoura University. Corresponding author: mohamed.elashry@fagr.bu.edu.eg
}

\begin{abstract}
A feeding study was conduct to investigate the effect of dietary supplementation of xylanase on growth performance, feed utilization, digestive enzymes, proximate composition, hematological and serum biochemical parameters of Nile tilapia, Oreochromis niloticus fingerlings fed plant-based diets for 70 days. Three isonitrogenous (293 $\mathrm{g} \mathrm{kg} \mathrm{k}^{-1}$ crude protein) and isocaloric (18.42 $\mathrm{MJ} \mathrm{kg}^{-1}$ gross energy) diets were formulated. Each diet was supplemented with xylanase at levels; 0 (control), 0.5 and $1 \mathrm{~g} \mathrm{~kg}^{-1}$ diet. After 70 days, the highest weight gain, specific growth rate, protein efficiency ratio, protein productive value, fat retention, energy retention, and the best feed conversion ratio were recorded in fish fed either 0.5 or $1 \mathrm{~g}$ xylanase $\mathrm{kg}^{-1}$ diet. As well as, the addition of xylanase up to $0.5 \mathrm{~g} \mathrm{~kg}^{-1}$ diet increases the activity of lipase, amylase, and trypsin. The addition of xylanase significantly improved hemoglobin, hematocrit, red blood cells, white blood cells, total protein, albumin, and globulin compared with the control diet. On the other hand, the addition of xylanase increased low-density lipoprotein cholesterol. The highest values of growth hormone and phosphorus were observed in fish fed diets supplemented with $0.5 \mathrm{~g}$ xylanase $\mathrm{kg}^{-1}$ diet. Based on the obtained findings, it could be conclude that the useful using of xylanase as feed additive up to $0.5 \mathrm{~g} \mathrm{~kg}^{-1}$ diet for significantly enhancement the growth performance, feed utilization, endogenous enzyme activity, and physiological responses of $O$. niloticus.
\end{abstract}

Keywords: Tilapia, Exogenous xylanase, Plant protein, Growth, Physiological responses.

\section{Introduction}

Aquaculture is one of the fastest-growing sectors in the world and is expected to continue growing rapidly in the foreseeable future (FAO, 2018). The feed is the most expensive item in aquaculture industry subsequently, continuous growth and intensification of aquaculture production depends upon the development of sustainable cheap protein sources instead of fishmeal (FM) in aquafeeds that is widely used as a source of protein in the aquafeed industry (Hassaan et al., 2015; Hassaan et al., 2018). Increasing the manufacturing cost of FM allows feed manufacturers to search for alternative sustainable cheap sources of proteins other than FM such as plant protein and their by-products (Tacon and Metian, 2015). In recent years, several alternative plant protein sources in tilapia diets have been investigated to reduce FM levels in diets, such as cottonseed meal (El-Saidy and Gaber, 2004), okara meal (El-Saidy, 2011), fermented soybean meal (Hassaan et al., 2015), soy protein concentrate (Ribeiro et al., 2016), Jatropha meal (Hassaan et al., 2016), corn protein concentrate (Khalifa et al., 2018) and fermented sunflower meal (Hassaan et al., 2018), which were showed to be suitable as partial replacer of FM. However, total replacement of FM with plant protein has generally resulted in decrease in fish growth performance and feed utilization due to the presence of anti-nutritional factors (ANFs) like the non-starch polysaccharides (NSPs) (Sinha et al., 2011) or imbalance in essential amino acids (Cheng $\boldsymbol{e t}$ al., 2013).

Exogenous enzymes are widely used in feed industry to mitigate the problem of ANFs especially in plant protein diets, thereby improving the nutritive value (Forster et al., 1999), nutrients utilization (Cheng et al., 2013), and animal growth (Cheng $\boldsymbol{e t}$ al., 2013; Saputra et al., 2016). Furthermore, aquatic animals lack certain digestive enzymes like xylanase, so supplement plant protein diets with xylanase improve nutrients utilization through their ability to degrade NSPs in plant cell walls into xylose accordingly improve the efficiency of feed utilization (Ghosh and Mukhopadhyay, 2006). Xylanase has been widely used in the poultry (Pirgozliev et al., 2015) and livestock (Passos et al., 2015) industries to enhance energy and nutrient availability of plant ingredients, but little information are available about its application in aquafeed industry. Therefore, the present study was designed to evaluate the effect of the graded levels $\left(0.5\right.$ and $1 \mathrm{~g} \mathrm{~kg}^{-1}$ diet $)$ of xylanase on growth performance, endogenous enzyme activity, chemical composition, hematological, and serum biochemical parameters of Nile tilapia, Oreochromis niloticus fingerlings for 70 days.

\section{Materials and Methods}

\section{Experimental fish and culture technique}

Mono-sex $O$. niloticus $\mathrm{L}$. all-male fingerlings were obtained from a private farm (El-Sahaba hatchery, Tolmbat 7, Kafr Elsheikh Governorate, Egypt). Fish 
were acclimated to the experimental conditions in a concrete pond $(4 \times 2 \times 1.25 \mathrm{~m})$ for two weeks in the Experimental Fish Farm, Faculty of Agriculture, Benha University, Egypt. During the acclimation period, fish fed a commercial control diet (30\% crude protein) at a rate of $3 \%$ of the biomass, which was provided equal rations at 09:00 am and 3:00 pm to adapt to the artificial diet and the trial conditions. After the acclimatization period, the experimental fish were randomly distributed into six experimental fiberglass tanks $\left(0.5 \mathrm{~m}^{3}\right.$ for each) representing three treatments studied. A total of 360 mono-sex $O$. niloticus fingerlings with an average initial weight of $10.3 \pm 0.039 \mathrm{~g}$ were use in this trail. Fish randomly stocked with a rate of 20 fish per each tank $\left(0.5 \mathrm{~m}^{3}\right.$ for each, $40 \mathrm{Fish} / \mathrm{m}^{3}$ ), as two tanks (replications) for each treatment. Tilapia were hand-fed with the respective diet $3 \%$ of biomass three times daily at $09.00 \mathrm{am}, 11.00 \mathrm{am}$ and $3.00 \mathrm{pm}$. Fish were weighed every two weeks to adjusted the amount of feed fish according to the changes in body weight through the experimental period. The experimental tanks were housed in the green house and was supplied with underground water. Each tank supplied with an automatic heater (150 watts) to maintain the rearing fish water temperature at $26-28$
${ }^{\circ} \mathrm{C}$. About one-third of the water volume in each tank was daily replace by aerated freshwater after removing the accumulated excreta. All tested water quality criteria (temperature, $\mathrm{pH}$ value, dissolved oxygen (DO) and total ammonia) were suitable and within the acceptable limits for rearing Nile tilapia $O$. niloticus fingerlings (Boyd, 1990).

\section{Experimental diets}

Three isonitrogenous (293 $\mathrm{g} \mathrm{kg}^{-1}$ crude protein) and isocaloric (18.42 $\mathrm{MJ} \mathrm{kg}^{-1}$ gross energy) experimental diets were formulated and the proximate chemical composition of the experimental diets presented in Table 1. The free xylanase basal diet was used as a control group. The other two diets supplemented with 0.5 and $1 \mathrm{~g}$ xylanase $\mathrm{kg}^{-1}$ diet (xylanase as a product of Huvepharma, Antwerp, Belgium). All ingredients of diets were blended for 5 mins and thoroughly mixed with soybean oil and made into dry pellets using a laboratory pellet mill (A California Pellet Mill, San Francisco, CA, USA) at the National Institute of Oceanography and Fisheries, Cairo Governorate, Egypt, the temperature of pellets in this stage did not exceed than $40^{\circ} \mathrm{C}$. The pellets (2-mm die) dried for $4 \mathrm{~h}$ at opened air and stored at $-20{ }^{\circ} \mathrm{C}$ until used.

Table 1. Ingredients $\left(\mathrm{g} \mathrm{kg}^{-1}\right.$ diet) and proximate composition of the experimental diets (\% on dry matter basis)

\begin{tabular}{|c|c|c|c|}
\hline \multirow{2}{*}{ Ingredients } & \multicolumn{3}{|c|}{ Experimental diets } \\
\hline & Control & $0.5 \mathrm{~g}$ xylanase $\mathrm{kg}^{-1}$ & $1 \mathrm{~g}$ xylanase $\mathrm{kg}^{-1}$ \\
\hline Soybean meal (44\% CP) & 450 & 450 & 450 \\
\hline Corn gluten & 60 & 60 & 60 \\
\hline Yellow corn & 170 & 170 & 170 \\
\hline Wheat bran & 150 & 149.50 & 149 \\
\hline Rice polishing & 100 & 100 & 100 \\
\hline Soybean oil & 40 & 40 & 40 \\
\hline Lysine & 5 & 5 & 5 \\
\hline Methionine & 5 & 5 & 5 \\
\hline Vit. \& Mine. ${ }^{1}$ & 15 & 15 & 15 \\
\hline Vitamin C & 5 & 5 & 5 \\
\hline Xylanase $\left(\mathrm{g} \mathrm{kg}^{-1}\right)$ & 0 & 0.5 & 1 \\
\hline \multicolumn{4}{|l|}{ Chemical analysis \% } \\
\hline Dry matter & 89.53 & 89.03 & 89.01 \\
\hline Crude protein $(\mathrm{CP})$ & 29.32 & 29.30 & 29.22 \\
\hline Crude lipid & 6.06 & 6.06 & 6.03 \\
\hline Ash & 5.07 & 5.06 & 5.03 \\
\hline Crude fiber & 6.47 & 6.40 & 6.35 \\
\hline $\mathrm{NFE}^{2}$ & 53.08 & 53.18 & 53.37 \\
\hline Gross energy $\left(\mathrm{MJ} \mathrm{kg}^{-1}\right)^{3}$ & 18.42 & 18.43 & 18.44 \\
\hline
\end{tabular}

${ }^{1}$ Each one $\mathrm{Kg}$ of vitamins and minerals mix. contains $\mathrm{MnSO}_{4}, 40 \mathrm{mg} ; \mathrm{Mg} \mathrm{O}, 10 \mathrm{mg} ; \mathrm{K}_{2} \mathrm{SO}_{4}, 40 \mathrm{mg} ; \mathrm{ZnCO}_{3}, 60 \mathrm{mg}$; KI, $0.4 \mathrm{mg}$; $\mathrm{CuSO}_{4}, 12 \mathrm{mg}$; Ferric citrate, $250 \mathrm{mg} ; \mathrm{Na}_{2} \mathrm{SeO}_{3}, 0.24 \mathrm{mg}$; Co, $0.2 \mathrm{mg}$; retinol, $40000 \mathrm{IU}$; cholecalciferol, $4000 \mathrm{IU} ; \alpha$-tocopherol acetate, $400 \mathrm{mg}$; menadione, $12 \mathrm{mg}$; thiamine, $30 \mathrm{mg}$; riboflavin, $40 \mathrm{mg}$; pyridoxine, $30 \mathrm{mg}$; cyanocobalamin, $80 \mathrm{mcg}$; nicotinic acid, $300 \mathrm{mg}$; folic acid, $10 \mathrm{mg}$; biotin, $3 \mathrm{mg}$; pantothenic acid, $100 \mathrm{mg}$; inositol, $500 \mathrm{mg}$.

${ }^{2} \mathrm{NFE}$ (Nitrogen free extract) $=100-$ (crude protein + lipid + ash + fibre content).

${ }^{3} \mathrm{Gross}$ energy calculated using gross calorific values of $23.63,39.52$ and $17.15 \mathrm{kj} \mathrm{g}^{-1}$ for protein, fat and carbohydrate, respectively according to Brett (1973). 


\section{Growth and feed utilization}

Records of live body weight (g) was measured in all experimental fish for each pond and were registered every 14 days (two weeks) during the experimental period (70 days). Growth performance and feed utilization indices parameters were calculated by using the following equations: Weight gain $(\mathrm{WG})$ = final body weight $(\mathrm{g})$ - initial body weight $(\mathrm{g})$; Specific growth rate $\left(\mathrm{SGR} \%\right.$ days $\left.^{-1}\right)=$ $\frac{\ln W 2-\ln W 1}{t} \times 100$, where: $\ln =$ the natural $\log ; \mathrm{W}_{1}=$ first fish weight; $\mathrm{W}_{2}=$ the following fish weight in grams; $\mathrm{t}=$ period in days. Feed conversion ratio $(\mathrm{FCR})=$ feed intake $(\mathrm{g}) /$ weight gain $(\mathrm{g})$; Protein efficiency ratio $($ PER $)=$ weight gain $(\mathrm{g}) /$ protein ingested $(\mathrm{g})$; Protein productive value $(\mathrm{PPV}) \%=(($ protein gain $(\mathrm{g}) /$ protein intake $(\mathrm{g})) \times 100$; Fat retention $(\mathrm{FR}) \%=$ Fat gain $(\mathrm{g}) /$ fat intake $(\mathrm{g}) \times 100$; Energy retention $(\mathrm{ER}) \%=$ Energy gain $(\mathrm{g}) /$ (energy intake) $\times 100$.

\section{Chemical composition}

The proximate chemical composition of fish and diet samples was determined according to the procedures of AOAC (1995). Dry matter (DM) was measured after drying the samples in an oven $\left(105^{\circ} \mathrm{C}\right)$ for $24 \mathrm{~h}$. Ash estimated by incineration at $550^{\circ} \mathrm{C}$ for $12 \mathrm{~h}$. Crude protein was determined by microKjeldahl method, N\% $\times 6.25$ (using Kjeltechauto analyzer, Model 1030, Tecator, Höganäs, Sweden) and crude fat by Soxhlet extraction with diethyl ether $\left(40-60^{\circ} \mathrm{C}\right)$. Crude fiber content was determined using the method of Van Soest et al. (1991). The nitrogenfree extract was compute by taking the sum of values for crude protein, crude lipid, crude fiber and ash content then subtracting this sum from 100.

\section{Determination of digestive enzymes activity}

Samples of intestine from three fish in each treatment were immediately homogenized in 10 volumes $\left(\mathrm{w} \mathrm{v}^{-1}\right)$ of ice-cold physiological saline solution and centrifuged at $5000 \mathrm{~g}$ for $15 \mathrm{~min}$. at $4{ }^{\circ} \mathrm{C}$; then the supernatant was stored for endogenous enzymes activity analysis (Furné et al., 2008). Trypsin activity was measured by using methods of Hummel (1959). Lipase activity was determine by a method described by Zamani et al. (2009), titration method detailed by using olive oil-gum. Amylase activity estimated according to Bernfeld (1951) at 540 $\mathrm{nm}$, starch used as a substrate.

\section{Blood sampling for hematological and biochemical indices}

At the end of the experiment, three fish were randomly selected from each treatment and euthanized with tricaine methanesulfonate $1 \mathrm{~g} \mathrm{~L}^{-1}$ for 5 minutes to collect the blood samples from the caudal vein of fish in all treatments and were divided into two portions. The first portion was collected with anticoagulant $10 \%$ ethylene diamine tetraacetate (EDTA) to determine the hematocrit (Htc), hemoglobin $(\mathrm{Hb})$, mean corpuscular volume (MCV), mean corpuscular hemoglobin $(\mathrm{MCH})$ and mean corpuscular hemoglobin concentration (MCHC), red blood cells (RBCs) count and total white blood cells (WBCs) count were done according to standard methods as described by Rawling $\boldsymbol{e t}$ al. (2009). The second portion of the blood sample collected without anticoagulant, allowed to clot at $4{ }^{\circ} \mathrm{C}$, and centrifuged at $3000 \mathrm{rpm}$ for $10 \mathrm{~min}$. to obtain the blood serum. The non-hemolyzed serum was collected and stored at -20 ${ }^{\circ} \mathrm{C}$ until used for measuring the serum biochemical parameters. Serum total protein and albumin were determined according to Henry (1974) and Wotton and Freeman (1982), respectively. However, globulin was calculated by subtracting albumin from total protein according to Coles (1974). Serum growth hormone $(\mathrm{GH})$ was measured by a radioimmunoassay (RIA) kit for Tianjin Nine Tripods Medical and Bioengineering Co., Ltd. (Tianjin, China), following the manufacturer's protocol. Serum total cholesterol, triglyceride, high-density lipoprotein cholesterol (HDL-C), low-density lipoprotein cholesterol (LDLC) and phosphorus were spectrophotometrically measured using commercial kits produced by Pasteur labs (Egyptian American Co. for Laboratory Services, Egypt).

\section{Statistical analysis}

All the obtained data were statistically analyzed by using SAS software (version 9.1) (SAS, 2004). All data submitted to a one-way analysis of variance (One-way ANOVA). Duncan's multiple range test was used to compare differences between treatment means when significant values were observed (Duncan 1955), at $(\mathrm{P}<0.05)$ level.

\section{RESULTS}

\section{Growth performance and feed utilization}

The growth performance and feed utilization of $O$. niloticus fed the experimental diets are illustrated in Table 2. Fish fed diet supplemented with $1 \mathrm{~g}$ xylanase $\mathrm{kg}^{-1}$ had the highest final body weights (FBW), WG and SGR. Feed intake was increased significantly with increasing the level of xylanase. Addition of xylanase to the feed also produced the better FCR, PER, PPV, $F R$, and ER with significantly $(P=0.0001)$ values higher than those un-supplemented diet with xylanase (control), more specifically in case of fish treated with $1 \mathrm{~g}$ xylanase $\mathrm{kg}^{-1}$ diet.

Table 2.Growth performance and feed utilization of $O$. niloticus fed plant-based diets supplemented with xylanase 


\begin{tabular}{|c|c|c|c|c|c|}
\hline \multirow{2}{*}{ Items } & \multicolumn{3}{|c|}{ Treatments } & \multirow{2}{*}{ \pm SEM } & \multirow{2}{*}{$P$-values } \\
\hline & Control & $0.5 \mathrm{~g}$ xylanase $\mathrm{kg}^{-1}$ & $1 \mathrm{~g}$ xylanase $\mathrm{kg}^{-1}$ & & \\
\hline IBW (g/fish) & $10.30^{\mathrm{a}}$ & $10.50^{\mathrm{a}}$ & $10.52^{\mathrm{a}}$ & 0.0398 & 0.3176 \\
\hline FBW (g/fish) & $22.20^{\mathrm{b}}$ & $26.30^{\mathrm{a}}$ & $28.15^{\mathrm{a}}$ & 0.2589 & 0.0001 \\
\hline WG (g/fish) & $11.90^{\mathrm{b}}$ & $15.80^{\mathrm{a}}$ & $17.63^{\mathrm{a}}$ & 0.2259 & 0.0001 \\
\hline SGR $\left(\%\right.$ days $\left.^{-1}\right)$ & $1.10^{\mathrm{b}}$ & $1.42^{\mathrm{a}}$ & $1.40^{\mathrm{a}}$ & 0.0110 & 0.0001 \\
\hline FI (g/fish) & $25.78^{b}$ & $27.52^{\mathrm{a}}$ & $27.56^{\mathrm{a}}$ & 0.2121 & 0.0001 \\
\hline FCR & $2.16^{\mathrm{a}}$ & $1.74^{\mathrm{b}}$ & $1.56^{\mathrm{c}}$ & 0.0385 & 0.0001 \\
\hline PER & $1.81^{\mathrm{b}}$ & $2.10^{\mathrm{a}}$ & $2.03^{\mathrm{a}}$ & 0.0115 & 0.0001 \\
\hline PPV (\%) & $26.12^{\mathrm{b}}$ & $35.25^{\mathrm{a}}$ & $34.41^{\mathrm{a}}$ & 0.5611 & 0.0001 \\
\hline $\mathrm{FR}(\%)$ & $35.57^{\mathrm{b}}$ & $47.88^{\mathrm{a}}$ & $45.24^{\mathrm{a}}$ & 0.8087 & 0.0001 \\
\hline $\operatorname{ER}(\%)$ & $13.97^{\mathrm{b}}$ & $18.20^{\mathrm{a}}$ & $18.56^{\mathrm{a}}$ & 0.3052 & 0.0001 \\
\hline
\end{tabular}

- Values ( \pm SEM, $n=3)$. Mean in the same row sharing the same superscript are not significantly different $(\mathrm{P}>0.05)$.

\section{Endogenous enzymes activity}

Table 3 showed that the supplementation of xylanase in the plant-based diets of Nile tilapia significantly increased the digestive enzymes. The highest activity of lipase, amylase, and trypsin at a level of $0.5 \mathrm{~g}$ xylanase $\mathrm{kg}^{-1}$ diet.

Table 3. Lipase, amylase, trypsin and chymotrypsin activities of $O$. niloticus fed plant-based diets supplemented with xylanase

\begin{tabular}{|c|c|c|c|c|c|}
\hline \multirow[b]{2}{*}{ Digestive enzyme } & \multicolumn{3}{|c|}{ Treatments } & \multirow{2}{*}{ \pm SEM } & \multirow{2}{*}{$P$-values } \\
\hline & Control & $0.5 \mathrm{~g}$ xylanase $\mathrm{kg}^{-1}$ & $1 \mathrm{~g}$ xylanase $\mathrm{kg}^{-1}$ & & \\
\hline Lipase $\mathrm{U} \mathrm{g}^{-1}$ & $3.75^{b}$ & $5.30^{\mathrm{a}}$ & $3.40^{\mathrm{c}}$ & 0.1415 & 0.0001 \\
\hline Amylase $\mathrm{U} \mathrm{g}^{-1}$ & $4.25^{\mathrm{b}}$ & $6.55^{\mathrm{a}}$ & $4.20^{\mathrm{b}}$ & 0.1814 & 0.0007 \\
\hline Trypsin $\mathrm{U} \mathrm{g}^{-1}$ & $26.00^{c}$ & $41.50^{\mathrm{a}}$ & $29.40^{\mathrm{b}}$ & 0.8540 & 0.0008 \\
\hline
\end{tabular}

- Values $( \pm$ SEM, $n=3)$. Mean in the same row sharing the same superscript are not significantly different $(\mathrm{P}>0.05)$.

\section{Chemical composition of whole fish}

As illustrated in Table 4, the addition of the graded levels $\left(0.5\right.$ or $1 \mathrm{~g} \mathrm{~kg}^{-1}$ diet $)$ of xylanase to plant-based diet for $O$. niloticus significantly decreased the dry matter $(\mathrm{P}=0.0001)$ and the crude lipid $(\mathrm{P}=0.0001)$ content. On the other hand, the opposite trend was observed for the crude protein $(\mathrm{CP})(\mathrm{P}=0.0001)$ and ash $(\mathrm{P}=0.0001)$ content where they were significantly increased.

Table 4. Proximate analysis (\% on dry matter basis) of $O$. niloticus fed plant-based diets supplemented with xylanase

\begin{tabular}{|c|c|c|c|c|c|}
\hline \multirow{2}{*}{ Proximate composition } & \multicolumn{3}{|c|}{ Treatments } & \multirow{2}{*}{ \pm SEM } & \multirow{2}{*}{$P$-values } \\
\hline & Control & $0.5 \mathrm{~g}$ xylanase $\mathrm{kg}^{-1}$ & $1 \mathrm{~g}$ xylanase $\mathrm{kg}^{-1}$ & & \\
\hline Dry matter & $26.35^{\mathrm{a}}$ & $25.45^{\mathrm{b}}$ & $25.2^{\mathrm{b}}$ & 0.0612 & 0.0001 \\
\hline Protein & $62.25^{\mathrm{a}}$ & $63.85^{\mathrm{b}}$ & $63.75^{\mathrm{b}}$ & 0.0540 & 0.0001 \\
\hline Lipid & $18.55^{\mathrm{a}}$ & $17.45^{\mathrm{b}}$ & $16.85^{\mathrm{b}}$ & 0.0346 & 0.0001 \\
\hline Ash & $15.65^{\mathrm{b}}$ & $16.90^{\mathrm{a}}$ & $17.10^{\mathrm{a}}$ & 0.0641 & 0.0001 \\
\hline
\end{tabular}

- Values $( \pm$ SEM, $n=3)$. Mean in the same row sharing the same superscript are not significantly different $(\mathrm{P}>0.05)$.

\section{Hematological parameters}

Data in Table 5 showed that fish fed supplemented diet with (0.5 and $1 \mathrm{~g} \mathrm{~kg}^{-1}$ diet) of xylanase was significantly $(\mathrm{P}=0.0001)$ increased the values of $\mathrm{Hb}$, Htc, MCV, MCH, MCHC, RBCs, and WBCs count compared with the control group.

Table 5. Hematological indices of $O$. niloticus fed plant-based diets supplemented with xylanase

\begin{tabular}{|c|c|c|c|c|c|}
\hline \multirow{2}{*}{ Hematology } & \multicolumn{3}{|c|}{ Treatments } & \multirow{2}{*}{ \pm SEM } & \multirow{2}{*}{$P$-values } \\
\hline & Control & $0.5 \mathrm{~g}$ xylanase $\mathrm{kg}^{-1}$ & $1 \mathrm{~g}$ xylanase $\mathrm{kg}^{-1}$ & & \\
\hline Hemoglobin $\left(\mathrm{g} / \mathrm{dL}^{-1}\right)$ & $5.55^{\mathrm{c}}$ & $11.35^{\mathrm{a}}$ & $9.55^{\mathrm{b}}$ & 0.0254 & 0.0001 \\
\hline Hematocrit $(\%)$ & $18.25^{\mathrm{b}}$ & $30.65^{\mathrm{a}}$ & $31.40^{\mathrm{a}}$ & 0.6858 & 0.0001 \\
\hline $\operatorname{MCV}(f l)$ & $122.5^{\mathrm{c}}$ & $145.50^{\mathrm{a}}$ & $135.50^{\mathrm{b}}$ & 0.3469 & 0.0001 \\
\hline $\mathrm{MCH}(\mathrm{g} / \mathrm{dL})$ & $57.50^{c}$ & $60.50^{\mathrm{a}}$ & $58.50^{\mathrm{b}}$ & 0.2886 & 0.0001 \\
\hline $\mathrm{MCHC}(\mathrm{pg})$ & $39.50^{c}$ & $41.50^{\mathrm{b}}$ & $43.00^{\mathrm{a}}$ & 0.2500 & 0.0001 \\
\hline RBCs $\left(\times 10^{6} \mu \mathrm{L}\right)$ & $1.84^{\mathrm{c}}$ & $3.65^{\mathrm{a}}$ & $3.27^{\mathrm{b}}$ & 0.0259 & 0.0001 \\
\hline WBCs $\left(\times 10^{3} \mathrm{~mm}^{-3}\right)$ & $87.70^{\mathrm{b}}$ & $125.80^{\mathrm{a}}$ & $125.60^{\mathrm{a}}$ & 0.2031 & 0.0001 \\
\hline
\end{tabular}

- Values $( \pm$ SEM, $n=3)$. Mean in the same row sharing the same superscript are not significantly different $(\mathrm{P}>0.05)$ 


\section{Biochemical blood parameters}

According to the obtained data of Table 6, values of the serum of total protein $(\mathrm{P}=0.0022)$, albumin $(\mathrm{P}$ $=0.0005)$ and globulin $(\mathrm{P}=0.0001)$ were significantly affected by the addition of different levels of xylanase ( 0.5 or $1 \mathrm{~g} \mathrm{~kg}^{-1}$ diet). On the other hand, addition of xylanase with both tested levels significantly decrease the total cholesterol $(\mathrm{P}=0.0001)$, and HDL-C $(\mathrm{P}=$ $0.0002)$, but significantly increase triglyceride $(\mathrm{P}=$
0.0001), and LDL-C $(\mathrm{P}=0.0001)$ compared with the control group. As noted in Figures 1 and 2 serum GH, and phosphorus were significantly $(\mathrm{P}<0.05)$ increased by the addition of different levels of xylanase $\left(0.5\right.$ or $1 \mathrm{~g} \mathrm{~kg}^{-1}$ diet $)$ compared with the control group, and the highest levels were obtained in fish fed diet supplemented with $0.5 \mathrm{~g}$ xylanase $\mathrm{kg}^{-1}$ diet.

Table 6. Blood biochemical parameters of $O$. niloticus fed plant-based diets supplemented with xylanase

\begin{tabular}{lccccc}
\hline \multirow{2}{*}{ Items } & \multicolumn{3}{c}{ Treatments } & \multirow{2}{*}{ SEM } & $P$-values \\
\cline { 2 - 4 } & Control & $0.5 \mathrm{~g} \mathrm{xylanase} \mathrm{kg}^{-1}$ & $1 \mathrm{~g} \mathrm{xylanase} \mathrm{kg}^{-1}$ & & 0.0003 \\
\hline Total protein $\left(\mathrm{g} \mathrm{dl}^{-1}\right)$ & $4.85^{\mathrm{c}}$ & $6.40^{\mathrm{a}}$ & $5.60^{\mathrm{b}}$ & 0.082 \\
Albumin $\left(\mathrm{g} \mathrm{dl}^{-1}\right)$ & $1.25^{\mathrm{b}}$ & $1.35^{\mathrm{a}}$ & $1.35^{\mathrm{a}}$ & 0.0289 & 0.0005 \\
Globulin $\left(\mathrm{g} \mathrm{dl}^{-1}\right)$ & $3.65^{\mathrm{b}}$ & $4.15^{\mathrm{a}}$ & $4.05^{\mathrm{a}}$ & 0.0288 & 0.0001 \\
Cholesterol $\left(\mathrm{mg} \mathrm{dl}^{-1}\right)$ & $198.00^{\mathrm{b}}$ & $178.00^{\mathrm{c}}$ & $208.00^{\mathrm{a}}$ & 0.5204 & 0.0001 \\
Triglyceride $\left(\mathrm{mg} \mathrm{dl}^{-1}\right)$ & $140.00^{\mathrm{c}}$ & $185.5 .00^{\mathrm{a}}$ & $189.00^{\mathrm{a}}$ & 0.4356 & 0.0001 \\
HDL-C $\left(\mathrm{mg} \mathrm{dl}^{-1}\right)$ & $38.00^{\mathrm{a}}$ & $38.50^{\mathrm{a}}$ & $35.50^{\mathrm{b}}$ & 0.3938 & 0.0002 \\
LDL-C $\left(\mathrm{mg} \mathrm{dl}^{-1}\right)$ & $88.50^{\mathrm{b}}$ & $108.00^{\mathrm{a}}$ & $103.00^{\mathrm{a}}$ & 0.3469 & 0.0001 \\
\hline
\end{tabular}

- Values $( \pm$ SEM, $n=3)$. Mean in the same row sharing the same superscript are not significantly different $(\mathrm{P}>0.05)$.

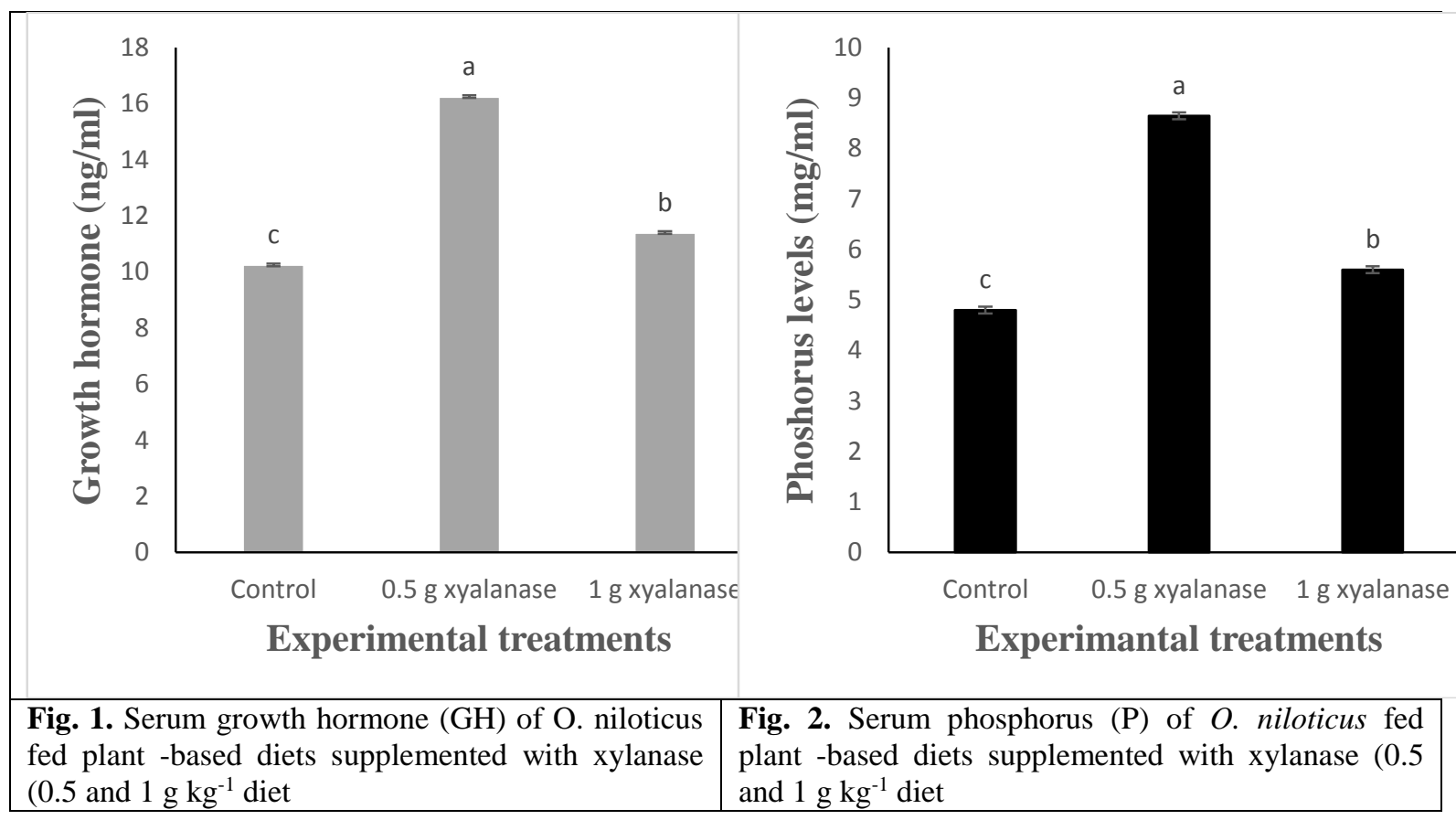

\section{Discussion}

The presence of ANFs in the plant-based diets reduced the utilization of nutrients of feed staff, which bind nutrients and reduce their bioavailability. Exogenous enzyme supplementation could be mitigated the effects of ANFs and enhance the nutrients assimilation (Farhangi and Carter, 2007; Lin et al., 2007; Soltan, 2009). Xylanase was incorporated to feed contained a high amount of plant protein with the purpose of increasing NSPs, thus enabling improved carbohydrate utilization (Adeola and Cowieson, 2011; Hassaan et al., 2019a) which has been shown to have beneficial effects on growth and physiological state of fish. In the present study, all parameters of growth performance; FBW, WG and SGR of Nile tilapia fed plant protein diet were improved by the addition of xylanase $\left(0.5 \mathrm{~g}\right.$ or $1 \mathrm{~g} \mathrm{~kg}^{-1}$ diet $)$. The improved in growth and feed utilization of fish fed plant-based diets supplemented with xylanase could be contributed to the degradation of NSPs to the level that the viscosity property of these fractions is largely reduced (Jiang et al., 2014; Hassaan et al., 2019a). The suppression of nutrients utilization by the addition of exogenous enzymes also due to their role for eliminating the ANFs effect (Farhangi and Carter, 2007; Lin et al., 2007; Soltan, 2009). The improved growth performance of Nile tilapia was showed with 
Natuzyme $50^{\circledR}$ supplementation was attributed to the presence of enzymes such as cellulase, xylanase and phytase in the cocktail that are not naturally produced by fish (Hlophe-Ginindza et al., 2016). Yildirim and Turan (2010), Ghomi et al. (2012), and Zamini et al., (2014) found a positive effect of various commercial multi-enzyme complexes (phytase, xylanase, $\beta$-glucanase, $\beta$-amylase, cellulase and pectinase) on the growth performance and feed efficiency of African catfish (Clarias gariepinus), great sturgeon (Huso huso) and Caspian salmon (Salmo trutta), respectively. However, no specified plant-based feedstuffs were used in any of these studies. In contrast, Ogunkoya et al. (2006) indicated that a commercial enzymes cocktail (xylanase, amylase, cellulase, protease, and $\beta$-glucanase) supplementation in soybean based diets did not affect the growth performance of rainbow trout.

Digestive enzymes play an important role in digestion of the nutrients for fish (Wen et al., 2009; Adeoye et al., 2016; Hassaan et al., 2019b). The present findings showed that the highest activities of digestive enzymes recorded in diet supplemented with $0.5 \mathrm{~g}$ xylanase $\mathrm{kg}^{-1}$ diet. This improved in digestive enzymes attributed to inhibit ANFs, high levels of fiber, and NSPs in plant-based diet, which increased the digestion (Hassaan et al., 2019b). Several authors showed that exogenous enzymes improved the activity of endogenous enzymes (Lin et al., 2007; Wei et al., 2010; Jiang et al., 2014; HlopheGinindza et al., 2016). This enhancement in the activity of endogenous enzymes may be attributed to the role of xylanase in the degradation products of arabinoxylans, hydrolyze cell wall components in the plant material, thereby it reduced the molecular size characteristics of NSPs content of the plant materials (Sinha et al., 2011; Ganguly et al., 2013).

Hematological indices regularly monitoring the information of physiological responses and nutritional status affecting aquatic animals (NRC, 2011). The current findings showed that $\mathrm{Hb}, \mathrm{Htc}, \mathrm{RBCs}$ and WBCs was significantly improved in fish fed plantbased diet supplemented with xylanase may be associated with decrease the ANFs binding iron and amine group of amino acids which in turn lowers their availability in the blood and increases the erythrocytes (Soltan, 2005). According to the increased number of RBCs multiplies the concentration of $\mathrm{Hb}$ ultimately resulting in a higher capacity for oxygen carrying in fish. While, Zamani et al. (2009) noted that no significant $(\mathrm{P}>0.05)$ difference of $\mathrm{Htc}, \mathrm{Hb}, \mathrm{RBCs}$, $\mathrm{MCV}, \mathrm{MCH}$ and $\mathrm{MCHC}(\mathrm{P}>0.05)$ in Caspian salmon (Salmo trutta caspius) fed supplemented diet with exogenous enzymes (Natuzyme ${ }^{\circledR}$ and Hemicell ${ }^{\circledR}$ ). The highest WBCs count also indicated that multienzymes including $\beta$-mannans, xylanase, in Hemicell and Natozyme crossing the intestinal mucosa are potent stimulators of the innate immune system, resulting in increased proliferation of macrophages and monocytes and resultant cytokine production (Ehsani and Torki, 2010).

The dietary xylanase was used in the present study caused elevated total protein, albumin and globulin levels in serum. Albumin and globulin are essential for a healthy immune system (TahmasebiKohyani et al., 2011). No data are available to discuss the effect of exogenous enzymes supplementation on the blood biochemical parameters, thus further studies are potentially required.

Lipid metabolism are usually express to triglyceride and lipoprotein in aquatic animal (Ma $\boldsymbol{e t}$ al., 2016). HDL-C aids in removal of cholesterol from the periphery for delivery to the liver and excretion into the bile (Norata et al., 2006) and LDL-C is the major cholesterol carrier in circulation and its physiological function is to convey cholesterol to the cells (Deng $\boldsymbol{e t}$ al., 2010). In the present study, serum total cholesterol and triglyceride content of Nile tilapia slightly increased with increasing the level of dietary xylanase; also lower content of HDL-C currently detected with xylanase supplementation due to hypocholesterolemic effects of high ANFs in plantbased protein. Since, more studies are necessity to clarify the effect of xylanase supplementation on lipid metabolism of plant-based diets of fish.

The dietary graded levels of xylanase was used in the present study increased the serum GH levels of Nile tilapia fed plant-based diet. The few data that have been published on the effect xylanase supplementation on the plant-based diets did not contained any information about of $\mathrm{GH}$, thus more studies well be needed.

\section{Conclusion}

It could be conclude that, using of xylanase up to $0.5 \mathrm{~g} \mathrm{~kg}^{-1}$ diet improved the growth performance, feed utilization, endogenous enzyme activity, hematological and blood biochemistry parameters of $O$. niloticus fingerlings. Yet, further studies are actually required for sharply determine the optimum level of xylanase not only for $O$. niloticus fingerlings, but also for other fish species or live stages. Additionally, the effects of xylanase on physiological or immune responses of fish and understanding the mechanisms of these effects are also necessity needed for advanced studies.

\section{References}

Adeola, O. and Cowieson, A. J. 2011. Opportunities and challenges in using exogenous enzymes to improve non-ruminant animal production. Journal of Animal Science, 89 (10): 3189-3218.

Adeoye, A. A.; Jaramillo-Torres, A.; Fox, S. W.; Merrifield, D. L. and Davies, S. J. 2016. Supplementation of formulated diets for tilapia (Oreochromis niloticus) with selected exogenous enzymes: Overall performance and effects on 
intestinal histology and microbiota. Animal Feed Science and Technology, 215:133-143.

AOAC, 1995. In: Cunni, P.A. (Ed.), Official Methods of Analysis of the Association Official Analytical Chemists, Vol. 1, 16th ed. AOAC International, Arlington, USA, p. 1298.

Bernfeld, P. 1951. Amylases $\alpha$ and $\beta$. In P. Colowick, \& N. O. Kaplan (Eds.), Methods in enzymology, 1: 149157. Academic Press, New York, USA.

Boyd, C. E. 1990. Water Quality in Ponds for Aquaculture. Alabama Agriculture. Experiment Station, Auburn University, Alabama.

Brett, J. R. 1973. Energy expenditure of Sockeye salmon Oncorhynchus nerka, during sustained performance. Journal of the Fish Research Board of Canada, 30:1799-1809.

Cheng, W.; Chiu, C. S.; Guu, Y. K.; Tsai, S. T. and Liu, C. H. 2013. Expression of recombinant phytase of Bacillus subtilis E20 in Escherichia coli HMS 174 and improving the growth performance of white shrimp, Litopenaeus vannamei, juveniles by using phytasepretreated soybean meal-containing diet. Aquaculture Nutrition, 19: 117-127.

Coles, E. H. (1974): Plasma proteins. In: Veterinary clinical pathology, 2nd edition. W.B. Saunders Co., Philadelphia, Pennsylvania, USA, pp. 558-560.

Deng, J.; Mai, K.; Ai, Q.; Zhang, W.; Wang, X.; Tan, B.; Xu, W.; Liufu, Z. and Ma, H. 2010. Interactive effects of dietary cholesterol and protein sources on growth performance and cholesterol metabolism of Japanese flounder (Paralichthys olivaceus). Aquac. Nutr. 16: 419-429.

Duncan, M. B. 1955. Multiple ranges and multiple Ftests. Biometrics, 11:1-42.

Ehsani, M. and Torki, M. 2010. Effects of dietary inclusion of guar meal supplemented by $\beta$-mannanase on performance of laying hens, egg quality characteristics and diacritical counts of white blood cells. Am J Animal Vet Sci., 5, 237-243.

El-Saidy, D. M. 2011. Effect of using okara meal, a byproduct from soymilk production as a dietary protein source for Nile tilapia (Oreochromis niloticus L.) mono-sex males. Aquaculture Nutrition, 17 (4): 380386.

El-Saidy, D. M. and Gaber, M. M. 2004. Use of cottonseed meal supplemented with iron for detoxification of gossypol as a total replacement of fishmeal in Nile tilapia, Oreochromis niloticus (L.) diets. Aquaculture Research, 35(9): 859-865.

FAO 2018. Food Agriculture Organization of the United Nations: The State of World Fisheries and Aquaculture 2018. MEETING THE SUSTAINBLE, Rome, Italy.

Farhangi, M., and Carter, C. G. 2007. Effect of enzyme supplementation to dehulled lupin-based diets on growth, feed efficiency, nutrient digestibility and carcass composition of rainbow trout, Oncorhynchus mykiss (Walbaum). Aquaculture Research, 38 (12): 1274-1282. https://doi.org/10.1111/j.13652109.2007.01789.x.
Forster, I.; Higgs, D. A.; Dosanjh, B. S.; Rowshandeli, M. and Parr, J. 1999. Potential for dietary phytase to improve the nutritive value of canola protein concentrate and decrease phosphorus output in rainbow trout (Oncorhynchus mykiss) held in $11^{\circ} \mathrm{C}$ fresh water. Aquaculture, 179:109-125.

Furné, M.; García-Gallego, M.; Hidalgo, M. C.; Morales, A. E.; Domezain, A.; Domezain, J. and Sanz, A. 2008. Effect of starvation and refeeding on digestive enzyme activities in sturgeon (Acipenser naccarii) and trout (Oncorhynchus mykiss). Comp. Biochem. Physiol., 149: 420-425.

Ganguly, A.; Das, S.; Bhattacharya, A.; Dey, A. and Chatterjee, P. K. 2013. Enzymatic hydrolysis of water hyacinth biomass for the production of ethanol: Optimization of driving parameters. Indian J Exp Biol 51(7):556-66.

Ghomi, M. R.; Shahriari, R.; Langroudi, H. F.; Nikoo, M. and Von Elert, E. 2012. Effects of exogenous dietary enzyme on growth, body composition, and fatty acid profiles of cultured great sturgeon Huso huso fingerlings. Aquac. Int. 20, 249-254.

Ghosh, K. and Mukhopadhyay, P. K. 2006. Application of enzymes in aqua feeds. Aqua Feeds Formulation Beyond, 3(4): pp.7-10.

Hassaan, M. S.; El-Sayed, A. I. M.; Soltan, M. A.; Iraqi, M. M.; Goda, A. M.; Davies, S. J.; ElHaroun, E. R. and Ramadan, H. A. 2019a. Partial dietary fish meal replacement with cotton seed meal and supplementation with exogenous protease alters growth, feed performance, hematological indices and associated gene expression markers (GH, IGF-I) for Nile tilapia, Oreochromis niloticus. Aquaculture, 503: 282-292.

Hassaan, M. S.; Goda, A. S. and Kumar, V. 2016. Evaluation of nutritive value of fermented de-oiled physic nut, Jatropha curcas, seed meal for Nile tilapia Oreochromis niloticus fingerlings. Aquaculture nutrition, 23(3):571-584.

Hassaan, M. S.; Mahmoud, S. A.; Jarmolowicz, S.; ElHaroun, E. R.; Mohammady, E. Y. and Davies, S. J. 2018. Effects of dietary baker's yeast extract on the growth, blood indices and histology of Nile tilapia (Oreochromis niloticus L.) fingerlings. Aquaculture nutrition, 24(6):1709-1717.

Hassaan, M. S.; Mohammady, E. Y.; Soaudy, M. R. and Abdel Rahman, A. A. 2019b. Exogenous xylanase improves growth, protein digestibility and digestive enzymes activities in Nile tilapia, Oreochromis niloticus, fed different ratios of fishmeal to sunflower meal. Aquaculture Nutrition, 25(4): 841853.

Hassaan, M. S.; Soltan, M. A. and Abdel-Moez, A. M. 2015. Nutritive value of soybean meal after solid state fermentation with Saccharomyces cerevisiae for Nile tilapia, Oreochromis niloticus. Animal Feed Science and Technology, 201:89-98.

Henry, R. J. 1974. Clinical Chemistry Principles and Techniques, 2nd ed. Harper and Row. Publ, New York, p. 525. 
Hophe-Ginindza, S. N.; Moyo, N. A.; Ngambi, J. W. and Ncube, I. 2016. The effect of exogenous enzyme supplementation on growth performance and digestive enzyme activities in Oreochromis mossambicus fed kikuyu-based diets. Aquaculture research, 47(12): 3777-3787.

Hummel, B. C. W. 1959. A modified spectrophotometric determination of chymotrypsin, trypsin and thrombin. Canadian Journal of Biochemistry and Physiology, 37 : 1393-1399. https://doi.org/10.1139/y59-157

Jiang, T. T.; Feng, L.; Liu, Y.; Jiang, W. D.; Jiang, J.; Li, S. H.; Tang, L.; Kuang, S. Y. and Zhou, S. Y. 2014. Effects of exogenous xylanase supplementation in plant protein-enriched diets on growth performance, intestinal enzyme activities and microflora of juvenile Jian carp (Cyprinus carpo var. Jian). Aqua. Nutrition 20: 632-645.

Khalifa, N. S. A.; Belal, I. E. H.; El-Tarabily, K. A.; Tariq, S. and Kassab, A. A. 2018. Evaluation of replacing fish meal with corn protein concentrate in Nile tilapia Oreochromis niloticus fingerlings commercial diet. Aquaculture Nutrition, 24(1): 143152.

Lin, S., Mai, K. and Tan, B. 2007. Effects of exogenous enzyme supplementation in diets on growth and feed utilization in tilapia, Oreochromis niloticus $x O$. aureus. Aquaculture Research, 38: 1645-1653.

Ma, F.; Li, X.; Li, B. and Leng, X. 2016. Effects of extruded and pelleted diets with differing lipid levels on growth, nutrient retention and serum biochemical indices of tilapia (Oreochromis aureus $\times$ Tilapia nilotica). Aquac. Nutr., 22: 61-71.

Norata, G. D.; Pirillo, A. and Catapano, A. L. 2006. Modified HDL: biological and physiopathological consequences. Nutr. Metab. Cardiovasc. Dis. 16: 371386.

NRC (2011): Nutrient Requirements of Fish and Shrimp. National academies press, Washington, DC, USA. https://doi.org/10.17226/13039

Ogunkoya, A. E.; Page, G. I.; Adewolu, M. A. and Bureau, D. P. 2006. Dietary incorporation of soybean meal and exogenous enzyme cocktail can affect physical characteristics of faecal material egested by rainbow trout (Oncorhynchus mykiss). Aquaculture, 254(1): 466-475.

Passos, A. A.; Andrade, C.; Phillips, C. E; Coffey, M. T. and Kim, S. W. 2015. Nutrient value of spray field forages fed to pigs and the use of feed enzymes to enhance nutrient digestibility. J. Animal Sci. 93: 17211728.

Pirgozliev, V.; Rose, S. P.; Pellny, T.; Amerah, A. M. and Wickramasinghe, M. 2015. Energy utilization and growth performance of chickens fed novel wheat inbred lines selected for different pentosane levels with and without xylanase supplementation. Poultry Sci., 94: 232-239.

Rawling, M. D.; Merrifield, D. L. and Davies, S. J. 2009. Preliminary assessment of dietary supplementation of Sangrovit ${ }^{\circledR}$ on red tilapia
(Oreochromis niloticus) growth performance and health. Aquaculture, 294:118-122.

Ribeiro, M. J. P.; Vidotti, R. M.; Ferreira, L. A. and Gonçalves, G. S. 2016. Evaluation of soy protein concentrate and meat and bone meal as a replacement for fishmeal in the diet of Nile tilapia fingerlings. Journal of the World Aquaculture Society, 47(3): 369375. https://doi.org/10.1111/jwas.12281.

Saputra, F.; Shiu, Y. L.; Chen, Y. C.; Puspitasari, A. W. and Danata, R. H. 2016. Dietary supplementation with xylanase-expressing B. amylolique faciens $\mathrm{R} 8$ improves growth performance and enhances immunity against Aeromonas hydrophila in Nile tilapia (Oreochromis niloticus). Fish Shellfish Immunol, 58: 397-405.

SAS 2004. Institute Inc. SAS/STAT 9.1 User's Guide. SAS Institute Inc., Cary, New York, USA.

Sinha, A.; Kumar, V.; Makkar, H.; De Broeck, G. and Becker, K. 2011. Non-starch polysaccharides and their role in fish nutrition - A review. Food Chemistry, 127:1409-1426.

Soltan, M. 2005. Potential of using raw and processed canola seed meal as an alternative fishmeal protein source in diets for Nile tilapia (Oreochromis niloticus). Egyptian J. Nutrition and Feed. 8: 1111-1128.

Soltan, M. 2009. Effect of dietary fishmeal replacement by poultry byproduct meal with different grain source and enzyme supplementation on performance, feces recovery, body composition and nutrient balance of Nile Tilapia. Pakistan Journal of Nutrition, 8(4): 395407. https://doi.org/10.3923/pjn.2009.395.407.

Tacon, A. G. and Metian, M. 2015. Feed matters: Satisfying the feed demand of aquaculture. Reviews in Fisheries Science and Aquaculture, 23(1): 1-10.

Tahmasebi-Kohyani, A.; Keyvanshokooh, S.; Nematollahi, A.; Mahmoudi, N. and PashaZanoosi, H. 2011. Dietary administration of nucleotides to enhance growth, humoral immune responses, and disease resistance of the rainbow trout (Oncorhynchus mykiss) fingerlings. Fish \& shellfish immunology, 30(1), 189-193.

Van Soest, P. J.; Robertson, J. B. and Lewis, B. A. 1991. Methods for dietary fiber, neutral detergent fiber, and nonstarch polysaccharides in relation to animal nutrition. J. Dairy Sci., 74:3583-3597

Wei, L.; Xiu-Mei, Z. and Li-Bo, W. 2010. Digestive enzyme and alkaline phosphatase activities during the early stages of Silurus soldatovi development. Zoological Research, 31(6): 627-632.

Wen, Z. P.; Zhou, X. Q.; Feng, L.; Jiang, J. and Liu, Y. 2009. Effect of dietary pantothenic acid supplement on growth, body composition and intestinal enzyme activities of juvenile Jian carp (Cyprinus carpio var. Jian). Aquaculture Nutrition, 15(5): 470-476.

Wotton, I. D. and Freeman, H. 1982. Microanalysis in Medical Biochemistry. Churchill, New York, USA.

Yildirim, Y. B. and Turan, F. 2010. Effect of exogenous enzyme supplementation in diets on growth and feed utilization in African catfish (Clarias gariepinus). Journal of Animal and Veterinary Advances, 9(2): 327-331. 
Zamani, A.; Hajimoradloo, A.; Madani, R. and Farhangi, M. 2009. Assessment of digestive enzymes activity during the fry development of the endangered Caspian brown trout Salmo caspius. Journal of Fish Biology, 75(4): 932-937.
Zamini, A.; Kanani, H.; Esmaeili, A.; Ramezani, S. and Zoriezahra, S., 2014. Effects of two dietary exogenous multi-enzyme supplementation, Natuzyme ${ }^{\circledR}$ and betamannanase $\left(\right.$ Hemicell $\left.^{\circledR}\right)$, on growth and blood parameters of Caspian salmon (Salmo trutta caspius). Comp. Clin. Pathol. 23: 187-192.

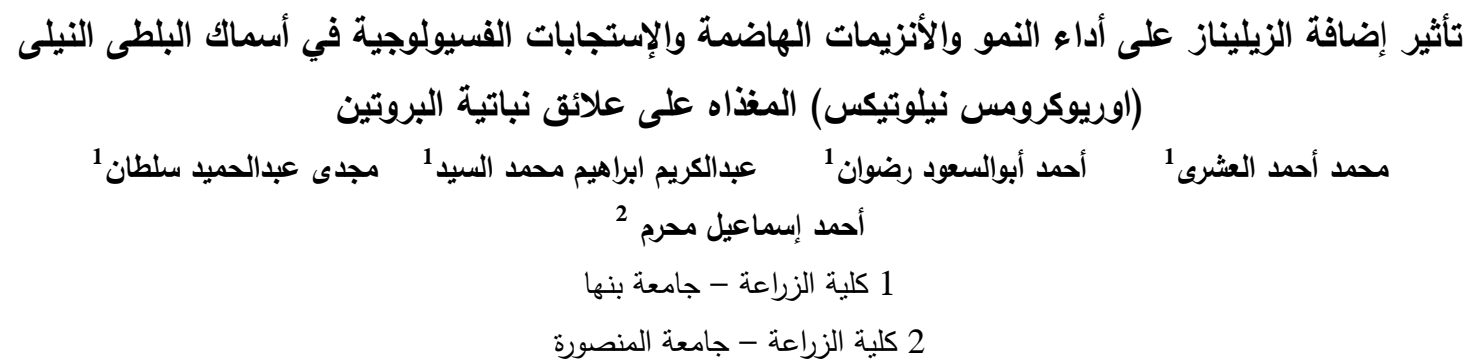

أجريت تجربة تغذية لمدة 70 يوم لدراسة تأثير إضافة انزيم الزيليناز على أداء النمو والإستفادة من الغذاء ونشاط الإنزيمات الداخلية والتركيب

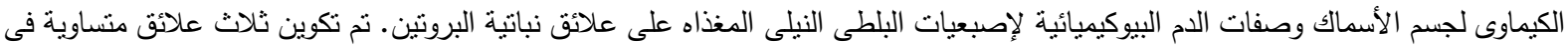
محتواها من البروتين (293 جرام/ كجم بروتين خام) والطاقة (18.43 ميجا جول/كجم علف طاقة كلية) وتم إضافة 3 مستويات من إنزيم الزبليناز

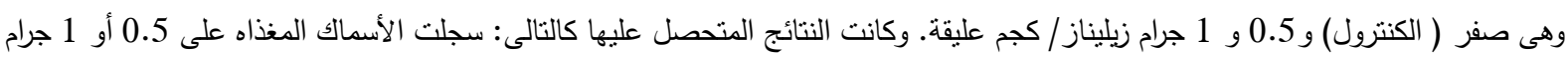
زيليناز / كجم عليقة أعلى وزن مكتسب ومعدل نمو نسبي ومعدل كفاءة للبروتين وقيمة إنتاجية للبروتين وأعلى قيم دهن وطاقة محتجزة بالجسم كما أعطت أفضل كفاءة لتحويل الغذاء. كما أدت إضافة الزيليناز بمستوى 0.5 جم/ كجم عليقة الى زيادة نشاط إنزيمات كلا من الليبيز , الأميليز والتربسين. أدت إضافة الزيليناز بمعدل 0.5 أو 1 جم/ كجم إلى تحسين قيم الهيموجلوبين , الهيماتوكريت , كرات الدم الحمراء, البروتين الكلي , الألبيومين , الجلوبيولين , عنصر الفوسفور معنويا مقارنة بالمجموعة الكنترول. سجلت الأسماك المغذاه على علائق مزودة الزيليناز بمعدل 0.5

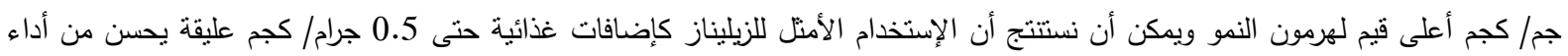
النمو , الإستفادة من الغذاء ونشاط الإنزيمات الداخلية والإستجابات الفسيولوجية المختلفة في أسماك البلطى النيلى. 